\title{
The Effect of Organizational Culture, Human Resources Quality And Work Motivation on Nurse Performance (In M.Djamil Central Hospital)
}

\author{
Levi Sastra ${ }^{1}$,Bustari Muchtar ${ }^{2}$, Sulastri ${ }^{3}$ \\ 1Universitas Negeri Padang, Padang, Indonesia, $\square$ levisastra8@gmail.com \\ ${ }^{2}$ Universitas Negeri Padang, Padang, Indonesia, $\bowtie$ bustarimuchtar@yahoo.com \\ ${ }^{3}$ Universitas Negeri Padang, Padang, Indonesia, $\square$ lastri_feunp@yahoo.com
}

\begin{abstract}
The purpose of this study was to analyze the Influence of organizational culture, quality of human resources and work motivation on nurse performance at M.djamil central hospital. Pulses in this study were 839 nurses. Looking at a large population, sampling was done by proportional random sampling technique, by determining the number of samples using the slovin formula at a confidence level of $95 \%$ and an error rate of $5 \%$ so that a sample of 280 nurses was obtained. The analysis technique used is Structural Equation Model (SEM) to determine the impact of the influence of organizational culture, quality of human resources and work motivation on performance. The results of the study show that Organizational Culture has a significant effect on the quality of human resource nurses then Organizational Culture and Quality of human resources have a significant effect on the motivation of nurse work. And work motivation and quality of human resources influence the performance of nurses at M.djamil central hospital.
\end{abstract}

Keywords: organizational culture, human resources quality, work motivation, employes performance.

\section{Introduction}

Organizational culture is a driving factor for the formation of performance. Because organizational culture is the values and norms that apply to the organization and accepted by all members of the organization. A good assessment of organizational culture can encourage employees to work better and ultimately can improve the performance of individuals within the organization. As stated by Tiernay quoted by Djokosantoso (2003) that the better the quality of the factors contained in organizational culture, the better the performance of the organization.

Quality of human resources is a very important factor in an organization, because humans always have an active and dominant role in every organizational activity starting from planning, actors and determinants of the realization of organizational goals so that it can be said that organizational goals will be realized if supported by quality human resources. This is reinforced by Siagian's statement (2009) which states that organizational dependence on increasingly high-quality human resource management will be even greater, without reducing the importance of attention that must still be given to the management of other organizational resources, there is no denying that attention the main cannot be given to human resource management.

Motivation represents the psychological process that causes it to occur, directed and there is the persistence of voluntary activities directed towards certain goals. According to Fahmi (2012), every individual actually has a motivation that is able to become a spirit in spurring and fostering enthusiasm for work. A person's spirit is sourced from himself or from the outside, where both forms will be better if both of them together contribute to one's motivation.

The effort to achieve organizational goals is inseparable from how a leader enhances the performance of his employees through motivation, because basically employees also have different needs and expectations.

This study explains the influence of Organizational Culture, Quality of Human Resources and Work Motivation on Nurse Performance at M.Djamil central hospital. The literature review is explained in the article's initial article which then explains the conceptual framework and research hypothesis. The next section explains the research methods, samples, and data analysis techniques. Then, the results of the study are discussed to answer the proposed hypothesis. In the end, explain the conclusions and suggestions from the results of this study. 


\section{Conseptual Development And Hypotheses Of Research Performance}

Performance is the overall value expected by a company from a series of different behaviors that are carried by individuals to the end of the standard period of time (Calvin, 2017). Employee performance is employee behavior or actions related to the goals or objectives of the organization concerned (Qatmeemalmarhoon, et al, 2017). Organizational culture can help employee performance, because it creates an extraordinary level of motivation for employees to give their best ability to take advantage of the opportunities provided by their organization. According to Barney in Lado \& Wilson, the values shared together make employees feel comfortable working, have commitment and loyalty and make employees strive harder, improve employee performance and job satisfaction and maintain a competitive advantage. Based on some of the above meanings, it can be concluded that employee performance is the work of quality and quantity achieved by an employee in carrying out his duties in accordance with the responsibilities given to him.

\section{Organizational Culture}

Ndraha (2002) states that organizational culture in general is a group of basic mindsets or mental programs that are used to improve work efficiency and human cooperation that an organization has, understanding organizational culture according to Robbins and Judge (2013). distinguishes the organization from other organizaztion "which means organizational culture is a system of values possessed by all members of the organization that distinguishes the organization from other organizations. Organizational culture can be permanent for a long period of time, but it is never static. Therefore, companies need to reevaluate the values, actions, and norms that exist within the company. organizational culture is a characteristic that exists in an organization and becomes the guideline of the organization so that it distinguishes it from other organizations. In other words, organizational culture is a norm of behavior and values that are understood and accepted by all members of the organization and are used as a basis in the rules of behavior in the organization.

\section{Quality of Human Resources}

The success achieved by an organization in achieving its objectives is inseparable from the quality of human resources who work together in supporting the activities of the organization. According to Siagian (2002) the quality of human resources is the level of productivity of a person in the organization to carry out tasks while increasing the determination to achieve goals that have been set smoothly and organized. According to Hasibuan (2003) the quality of human resources is a person's ability to regulate relations and the role of labor to realize the goals of the company, employees and the community as well as their functions which consist of planning, organizing, maintenance, discipline and dismissal.

\section{Work Motivation}

One of the most influential aspects of achieving an organizational goal is the motivation of human resources work in the organizational environment. The importance of motivation because motivation is the thing that causes, channels, and supports human behavior, so that they want to work hard and are enthusiastic about achieving optimal results. The motivation according to Robbins (2010: 166) is the willingness to issue a high level of effort for organizational goals that is conditioned by the ability of his own efforts in meeting several individual needs. Needs occur when there is no balance between what is owned and what is expected. Encouragement is a mental force oriented to meeting expectations and achieving goals. And goals are goals or things that an individual wants to achieve. 


\section{Conceptual framework}

Conceptual research, which can be seen in the figure below

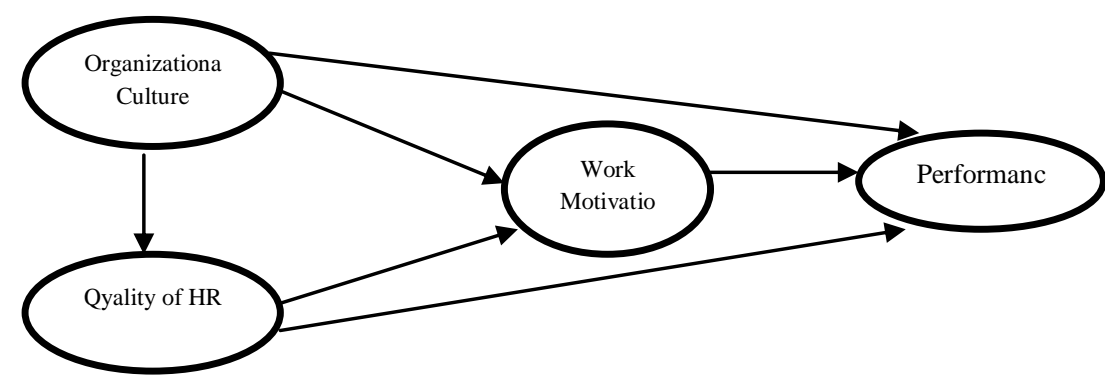

Figure 1 Conceptual Framework

\section{Hypothesis}

H1: Organizational culture has a positive and significant effect on the employee performance of M. Djamil central public hospital Padang

Pettigew in Sabirin (2009) argues that organizational culture is a system of meaning that is accepted openly and collectively which applies to a certain time for a group. Research conducted by Hodge and Anthony in Sopiah (2008) states that organizational culture has a positive effect on performance; Strong culture can be seen from the high agreement among employees about what is maintained by the organization. Based on the opinion above it can be concluded that organizational culture can improve performance, both employee performance and overall organizational performance. Organizational culture is able to provide a positive contribution to the improvement of employee behavior in an organizational environment which can ultimately help the organization achieve its intended goals

H2: Organizational culture has a significant positive effect on the Motivation of M. Djamil Central public hospital.

The development of the quality of human resources according to Mangkuprawira (2003) is an effort to improve technical capabilities, theoretical abilities, conceptual abilities of moral enhancement and improvement of human technical skills through education and training. The purpose of HR development is to improve the effectiveness and efficiency of work in implementing and achieving the goals of the organization's work programs that have been set. The better the quality of human resources, which is characterized by the ability and skills that are good at carrying out good in carrying out tasks, the higher the performance of the employees concerned. Conversely, employees with relatively low quality human resources are characterized by low ability and work skills will have difficulty in completing tasks that are charged so that their performance is also low. Thus there is a unidirectional relationship between the quality of human resources and employee performance. This is reinforced by the opinion of Pribadi and Yani (2003) who said that the better the quality of human resources the better the work ability of employees and ultimately can have a positive impact on improving performance.

H3: Organizational culture significantly positive influence on the quality of employee human resources of the central general hospital of M. Djamil Padang.

Motivation is a condition or energy that directs employees who are directed or aimed at achieving the goals of the company's organization. It is the mental attitude of employees who are pro and positive towards work situations that strengthen their work motivation to achieve maximum performance. The mental attitude of employees must have a psychophysically prepared mental attitude (ready to mentally and physically reflect the purpose). Employees in working mentally ready, physically healthy, understanding the situation and conditions and striving to achieve work targets (Mangkunegara, 2005)

H4: The quality of human resources influences positive significance towards employee performance of the central public hospital of M. Djamil Padang 
A good assessment of organizational culture can encourage employees to work better and ultimately can improve the performance of individuals within the organization. As stated by Tiernay quoted by Djokosantoso (2003) that the better the quality of the factors contained in the organizational culture, the better the performance of the organization and this certainly is closely related to motivation in work. This is relevant to the results of research Hernita (2015) states that organizational culture has a positive and significant influence on work motivation.

H5: The quality of human resources has an effect on the work motivation of the M.Djamil Central Hospital.

Employees who already understand the overall culture and organizational values will make these values an organizational personality. These values and beliefs will be manifested into daily behavior in work, so that it will be influential on the quality of human resources itself, it is relevant to the results of research Rahmady (2017) states that organizational culture has a positive and significant effect on the quality of human resources.

H6: Work motivation has a significant effect on the employee performance of M. Djamil central public hospital Padang

One specific indicator of quality is the skill possessed by employees. The performance of an employee is good if he has high expertise. (Tampubolon, 2007) This means that nurses with better quality will have good performance, so there is a positive correlation between the two qualities with work motivation. This is relevant to the results of research conducted by Dahniar et al (2017) stating that quality has a positive and significant effect on the work motivation of an employee.

\section{Research Methodology \\ Type of Research}

This study uses a quantitative approach. The analysis technique used is Structural Equation Model (SEM) to determine the effect of organizational culture, human resource quality and work motivation on nurse performance at M. Djamil central general hospital.

\section{Sampling Techniques}

The technique of collecting data in this study was using a questionnaire. The population all nurses in RSUP M. Djamil Padang. The number of samples in this study were 280 respondents.

\section{Results and Discussion}

This study uses Structural Equation Modeling (SEM) analysis. The Measurement Model shows how the manifest variable (indicator) presents latent variables to be measured, namely by testing the validity and reliability of latent variables through confirmatory factor analysis (CFA). On the results of confirmatory factor analysis the Chi Square value of 1188,328 0.057 probability level value indicates that this model is in accordance with the data or fit .

\section{Structural Results Model}

The structural model shows a chi-square of 1188,328 . The results show that the values of CMIN / Df, RMSEA, TLI, CFI, GFI, and AGFI are in accordance with the criteria. This means that the model is fit and feasible to use. The goodness-of-fit model test results are explained in the following table: 
Table 1 Test Results Goodness-of-fit Model

\begin{tabular}{lccc}
\hline $\begin{array}{l}\text { Goodnes of fit } \\
\text { index }\end{array}$ & \multicolumn{1}{c}{ Cut off value } & Model results & Information \\
\hline Chi-Square $\left(x^{2}\right)$ & $\begin{array}{l}\text { Re-estimate value must be } \\
\text { smaller }\end{array}$ & 1188.328 & Fit \\
\hline $\begin{array}{l}\text { Significated } \\
\text { probability }\end{array}$ & $\geq 0,05^{*}$ & 0,057 & Fit \\
\hline RMSEA & $\leq 0.08^{*}$ & 0,097 & Fit \\
\hline CFI & $0-1$ & 0,969 & Fit \\
\hline AGFI & $0-1$ & 0,941 & Fit \\
\hline CMIN/DF & $\leq 3.00$ & 0,994 & Fit \\
\hline GFI & $0-1$ & 0,945 & Fit \\
\hline
\end{tabular}

Based on the table above it can be seen that the value of Chi Square is 1188,328 with a probability level of 0.057, the evaluation model in this study is fit. CMIN / DF is 0.994 small than 3.00 so the conclusion of the evaluation model is fit. The CFI value is 0.969 between the values of $0-1$, the conclusion of the evaluation model is fit. The RMSEA value is 0.057 small from 0.08 so the conclusion of the evaluation model is fit. The GFI value is 0.945 between the values of $0-1$, then the conclusion of the evaluation model is fit. Based on the explanation above, it can be concluded that the model in this study is fit, the number of criteria is close to the characteristics of fit, so the model in this study is feasible to use.

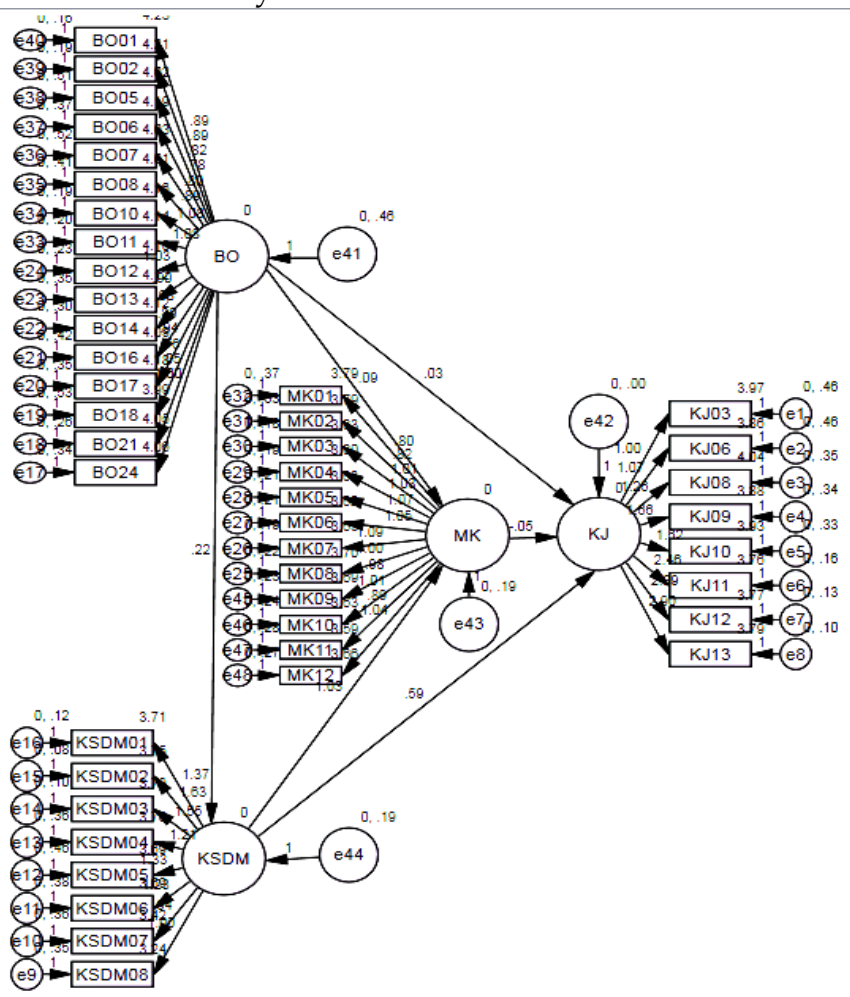

Chi-square $=1188.328$

Probability $=0,057$

$\mathrm{CMIN} / \mathrm{DF}=3,019$

AGFI $=0,941$

TLI $=0,945$

$\mathrm{CFI}=0,969$

RMSEA $=0,097$

Figure 2 Structural Model 


\section{Hypothesis Testing Results}

The estimated goodness of fit structural model criteria can be fulfilled, then the next step is the analysis of the relationship of structural models. The relationship between constructs in the hypothesis is indicated by the value of regression weights below:

Table 2 Regession Weights

\begin{tabular}{lllrrrrr}
\hline & & & Estimate & S.E. & C.R. & P & Label \\
\hline Human Resources & $<---$ & Organizational Culture & .221 & .045 & 4.872 & $* * *$ & par_43 \\
\hline Work Motivation & $<--$ & Organizational Culture & .088 & .046 & 1.985 & $* * *$ & par_41 \\
\hline Work Motivation & $<---$ & Human Resources & 1.030 & .112 & 9.173 & $* * *$ & par_42 \\
\hline Performance & $<---$ & Work Motivation & .051 & .014 & 3.605 & $* * *$ & par_44 \\
\hline Performance & $<---$ & Human Resources & .593 & .108 & 5.486 & $* * *$ & par_45 \\
\hline Performance & $<---$ & Organizational Culture & .028 & .008 & 3.337 & $* * *$ & par_46 \\
\hline
\end{tabular}

\section{Discussion}

Based on the results of the analysis of organizational culture variables have a significant effect on the quality of human resource nurses at M.Djamil Central Hospital, which can be seen from the t-statistical value in Table 4.29 obtained by the $C R$ value of $4.872>1.96$ and $p$ (probability worth ${ }^{* * *}$ ). Because the value of a small probability of the error value rejects data 0.05 , or CR which is the value of $t$ count large from the value of $t$-table. So it can be concluded that if the organizational culture is better then the quality of nurses at M.Djamil Central Hospital will improve. This finding is also in accordance with previous research conducted by Armisyurita (2016) with the research title "The Influence of Organizational Culture and the Quality of Human Resources and Their Effects on Employee Work Performance". His research results show that organizational culture influences the quality of human resources (HR).

Based on the results of the analysis of organizational culture variables significantly influence the motivation of nurses working at M.Djamil Central Hospital, which can be seen from the t-statistical value in Table 4.29 , the CR value is $1.985>1.96$ and $p$ (probability) worth ${ }^{* * *}$. Because the value of a small probability of the error value rejects data 0.05 , or $C R$ which is the value of $t$ count large from the value of $t$-table. So it can be concluded if the organizational culture has been better then the work motivation of M.Djamil Central Hospital will improve. This finding is also in line with the research conducted by Ida et al. (2017) with the research title "The Influence of Organizational Culture on Work Motivation and Employee Performance of Klumpu Bali Resort Sanur". The results show that organizational culture influences employee motivation.

Based on the results of the variable quality analysis of HR on nurses' work motivation at M.Djamil Central Hospital, which can be seen from the t-statistical value in Table 4.29, the CR value is 9.173>1.96 and $\mathrm{p}$ (probability worth ${ }^{* * *}$ ). Because the value of a small probability of the error value rejects data 0.05 , or $\mathrm{CR}$ is the value of $t$ calculated large from the value of $t$-table. So it can be concluded that if the organizational culture is better then the quality of nurses at M.Djamil Central Hospital will improve. This finding is also in accordance with previous research conducted by Novitasari (2014) with the research title "The Influence of Quality of Human Resources and Work Motivation on the Work Achievement of Kud Margorejo Pati Patients in 2014". The results show the quality of HR has a positive effect on employee motivation.

Based on the results of the analysis of cultural variables, motivation has a significant effect on nurses' performance at M.Djamil Central Hospital, which can be seen from the t-statistical value in Table 4.29, the $\mathrm{CR}$ value is 3,605> 1.96 and $\mathrm{p}$ (probability) worth ${ }^{* * *}$. Because the value of a small probability of the error value rejects data 0.05 , or $C R$ which is the value of $t$ count large from the value of $t$-table. So it can be concluded that if the nurse has been motivated in work, the nurse's performance in M.Djamil General Hospital Padang will also increase. This finding is in accordance with the research of Qatmeemalmarhoon, et al (2017) with the research title "Analysis of the effect of work motivation on performance". The results of the study are that motivation has a positive effect on employee performance and commitment. Commitment, and independent variables (motivation), are shown to have the greatest impact on employee performance.

Based on the results of the HR quality variable analysis has a significant effect on nurses' performance at M.Djamil Central Hospital, which can be seen from the t-statistic value in Table 4.29, the CR value is 5.486> 1.96 and $p$ (probability) worth ${ }^{* * *}$. Because the value of a small probability of the error value rejects data 0.05 , or $\mathrm{CR}$ which is the value of $\mathrm{t}$ count large from the value of $\mathrm{t}$-table. So it can be concluded if the quality of 
nurses has increased, it will affect the increase in nurses' performance in RSUP. M. Djamil itself. This finding is in accordance with the research conducted by Zozi (2013) with the research title "The Influence of Organizational Culture Leadership Style and Quality of Human Resources through Motivation on Employee Performance of Bukit Dua twelve National Park Office" whose results show a direct influence on the quality of HR on performance.

Based on the results of the analysis of organizational culture variables significantly influence the performance of nurses at M.Djamil Central Hospital which can be seen from the t-statistical value in Table 4.29 , the $C R$ value of 3,337> 1.96 and $p$ (probability) worth ${ }^{* * *}$ is obtained. Because the value of a small probability of the error value rejects data 0.05 , or CR which is the value of $t$ count large from the value of $t$ table. So it can be concluded that if the organizational culture is better then the quality of nurses at M.Djamil Central Hospital will improve. This finding is in accordance with the research conducted by Nurjanah (2018) with the research title "The Influence of Leadership Style and Organizational Culture in improving employee performance (Studies in the bureau of the scope of the agricultural department" which results show organizational culture has a positive effect on employee performance.

\section{Conclusions}

Based on the results of the analysis relating to the purpose of this study, then some conclusions can be drawn from the results of the study: organizational culture has a significant effect on the quality of nurses' human resources in M.Djamil Central Hospital. organizational culture and quality of human resources have a significant effect on the Motivation of Nurses in hospital Padang. work motivation and quality of human resources affect the performance of nurses in M.Djamil Central Hospital.

Based on the conclusions above, there are a number of suggestions that the author proposes to the organization. It is expected that the superior / head of the M.Djamil Central Hospital will pay more attention to the performance of the nurse, because with good performance, the patient will feel comfortably served. In addition, the organization's goals will be quickly realized, because the service business pillar is its own human resources. In addition, the supervisor / head of the M.Djamil Central Hospital general hospital also needs to pay attention to the factors that affect the nurse's performance at the Central M.djamil general hospital itself.

\section{References}

Algopeng Z (2013). Pengaruh Gaya Kepemimpinan, Budaya Organisasi, dan Kualitas Sumber Daya Manusia melalui Motivasi Terhadap Kinerja Pegawai Pada Balai Taman Nasional Bukit Dua belas. Universitas Batanghari, Jambi. Tesis.

Amir Sohail, Robina Safdar dkk (2014). Effect of Work Motivation and Organizational Commitment on Job Satisfaction: (A Case of Education Industry in Pakistan). Global Journals Inc. (USA) Online ISSN: 2249-4588 \& Print ISSN: 0975-5853

Aritonang, Keke. T. 2005. Kompensasi Kerja, Disiplin Kerja Guru dan Kinerja Guru SMP Kristen BPK PENABUR. Jurnal pendidikan penabur. Jakarta

Chunli Liu (2017). Employee quality, monitoring environment and internal control, China Journal of acounting Research (2017).

Djokosantoso, Moeljono (2003). Budaya Koorporat dan Keunggulan Korporasi, Elex Media Komputindo, Jakarta.

Fakhar Shahzad, (2017). Organizational culture and innovation performance in Pakistans software industry, (Pakistan).Journal homepagewww.elsevier.com/locate/techsoc

Fattah (2014) Perilaku Pemimipin \& Kinerja Pegawai, Budaya Organisasi, Efikasi diri, dan Kepuasan Kerja. Elmatera. Yokyakarta.

Ghozali, Imam, (2011). Model Persamaan Struktural Konsep dan Aplikasi Dengan Program Amos 19,0 Semarang

Harun, Cut Hari (2003). Peningkatan Kualitas Sumber Daya Manusia Melalui Pendidikan Merupakan Kunci Keberhasilan Suatu Lembaga di Era Globalisasi dan Otonomi Daerah, Jurnal Pendidikan dan Kebudayaan, Balitbang Diknas.

Hasibuan, M.S.P (2003). Manajemen Sumber Daya Manusia, PT. Gunung Agung., Jakarta 
Latt, K. A., (2008). Motivating People on the way towards Organizational Performance. Victoria University (Australia), intern analyst, Covalence SA, Geneva.

Malthis dan Jackson (2002) Manajemen Sumber Daya Manusia, (Terjemahan; Jimmy Sadeli dan Bayu Perwira), Edisi Pertama, Salemba Empat, Jakarta.

Mangkuprawira, Syafri (2003) Manajemen Sumber Daya Manusia Strategik, Cetakan Kedua, Ghalia Kedua, Ghalia Indonesia, Jakarta

Mastuhu (2008) Menuju Sistem Pendidikan Yang Lebih Baik Menyongsong Era Baru Pasca Orba, Makalah: Disampaikan pada Diskusi Panel HMJ-KI IAIN Jakarta

Ndraha, Taliziduhu (2002). Pengantar Teori Pengembangan Sumber Daya Manusia, Rineka Cipta, Jakarta

Nikpour Amin, (2017). The impact of organizational culture on organizational performance: The mediating role of employee's organizational commitment.International Journal of Organizational Leadership (2017)

Oluseyi, S., \& Ayo, H. T., (2009). Influence of Work Motivation, Leadership Effectiveness and time Management on Employees' Performance in some Selected Industries in Ibadan, Oyo State, Nigeria. European journal of Economics, Finance and Administrative Sciences, 16, 7-17.

Onanda Belly (2015). The Effect Of Motivation on Job Performance A Case Study of KCB Coast Region. International Journal of Scientific and Research Publications, Volume 5, Issue 9, September 2015. ISSN 2250-3153

Sedarmayanti (2007) Manajemen Sumber Daya Manusia: Reformasi Birokrasi dan Manajemen Pegawai Negri Sipil, PT. Refika Aditama, Bandung.

Siagian, Sondang P, (2010) Teori \& Praktek Kepemimpinan. Rineka Cipta, Jakarta.

Sobirin A (2009). Budaya Organisasi, UPP STIM YKPM, Yogyakarta

Sopiah (2008) Perilaku Organisasional. ANDI. Yogyakarta

Sugiyono. (2011), Metode Penelitian Administrasi, Alfabeta, Bandung

Supriyadi (2014) SPSS + Amos Statistical Analysis in Media, Jakarta

Susanto, AB (2002) Budaya Perusahaan : Seri Manajemen Dan Persaingan Bisnis, Cetakan Pertama, Flex Media Komputindo, Jakarta

Tampubolon, Biatna D (2007). Analisis Faktor Gaya Kepemimpinan dan Faktor Etos Kerja Terhadap Kinerja Pegawai Pada Organisasi Yang Telah Menerapkan SNI 19-9001-2001

Tella, A., Ayeni, C. O., \& Popoola, S. O., (2007). Work Motivation, Job Satisfaction and Organizational commitment of Library Personel in Academic and Research Libraries in Oyo State, Nigeria. Library Philosophy and Practice, 1-16.

Umar, Husein (2008). Riset Sumber Daya Manusia Dalam Organisasi, Gramedia Pustaka Umum, Jakarta.

Wijaya T (2012). Cepat Menguasai SPSS 20 Untuk Olah dan Interpretasi Data. Cahaya Atma Pustaka, Yogyakarta.

Yoomin Nam, (2016). Influence Of Organizational Culture and Characteristcs On Job Attitude of Organizational Members in Seminductor Industry. (South Korea). Procedia Computer Science 91 (2016) 